\title{
Interval of Routine Maintenance and Maintenance Performance: A Literature Review
}

\author{
Cheong Peng Au-Yong ${ }^{1, a}$, Azlan Shah Ali ${ }^{1}$ and Shirley Jin Lin Chua ${ }^{1}$ \\ ${ }^{1}$ Department of Building Surveying, Faculty of Built Environment, University of Malaya, 50603 Kuala Lumpur, Malaysia.
}

\begin{abstract}
In high-rise residential buildings, the quality of facilities management services is significant to the normal operation of the facilities. Unfortunately, lack of concern towards building maintenance, especially preventive maintenance, happens in domestic housing industry in Malaysia. Majority of the maintenance operations of condominiums suffer from lack of planning, lack of proactive maintenance plan, and lack of proper implementation. Thus, this paper reviews the implementation of preventive maintenance strategy, routine maintenance in specific. An extensive review of literature published in 1987 to 2014 is performed for the purpose of this research. The publications are sourced from journal articles, conference proceedings and books. The literature analysis confirms that the routine maintenance of facilities and building services is vital and it can be influential towards the maintenance performance. Subsequently, a theoretical framework is developed, which shows the relationship between routine maintenance of building facilities \& services and maintenance performance. The building facilities \& services are divided into two categories. They are essential facilities \& services that ensure the safety, health, habitability, and operability of buildings; while value-added facilities \& services deal with property value, return on investment, and quality living of buildings. Based on the findings, a future research is proposed, which aims to identify the appropriate routine of maintenance for the facilities and services in high-rise residential buildings to improve the maintenance performance.
\end{abstract}

\section{Introduction}

In high-rise residential buildings, the quality of facilities management services is significant to the normal operation of the facilities such as lifts, ventilation system, mechanical and electrical installations, recreational and sport facilities, etc. [1]. Unfortunately, lack of concern towards building maintenance, especially preventive maintenance, happens in domestic housing industry in Malaysia [2, 3]. Hsieh [4] stated that majority of the maintenance operations of condominiums suffer from lack of planning, lack of proactive maintenance plan, and lack of proper implementation. As a result, many complaints of dissatisfaction with the dilapidated condition of the residential buildings and the poor conditions of facilities and services are recorded [5].

High maintenance cost is a common issue in construction industry [6]. Public neglects the importance of building maintenance as a result of the massive costs required for maintenance operations [7]. Meanwhile, ineffective planning of maintenance strategies and low service quality are another issues of maintenance management in Malaysia [8, 9]. Indeed, lack of knowledge about the maintenance strategies, inadequate performance standard, lack of building performance monitoring data, as well as failure to provide appropriate advice on design and planning based on overall performance are the factors that lead to the issues.

Specifically, lack of preventive measure is currently the problem that implicates poor maintenance outcome. Whereby, numerous researches introduce and recommend the scheduled maintenance as a strategy to tackle the issues [10-12]. However, the effectiveness of the maintenance strategy can be jeopardised by the inappropriate or inaccurate routine of inspection and maintenance [13-16]. Long interval between the maintenance actions to perform rehabilitation works as a result of insufficient funds, leads to the rise of deterioration rate and hence dissatisfaction of the residents [17].

The statements demonstrates the effect of poor maintenance management, especially the maintenance interval or maintenance frequency, towards the building performance. Therefore, this paper aims to propose a study about the relationship between frequencies of routine maintenance for the facilities and maintenance performance in high-rise residential buildings. The next section provides a brief background about the maintenance management in building property sector and explores the building maintenance trend in international and local contexts.

\footnotetext{
${ }^{a}$ Corresponding author: auyongcp@um.edu.my
} 


\section{Background}

In property sector, the maintenance operation of condominiums in Taiwan suffers from lack of planning. Hsieh [4] analysed that 52 percent of the management committees do not have proactive maintenance plan or any annual operation programmes. However, 16 percent of them do have the plan or programmes but without proper implementation. As a result majority of the condominiums operate their own condominium on an ad hoc basis, which is corrective maintenance.

In Malaysian context, buildings have not been effectively and well maintained throughout the years, though there is commitment from the government towards building maintenance. The building residents neglect the importance of maintenance. Lateef [7] noted that building maintenance in Malaysia is conditionally driven and is usually concerned when there is cost allocation. There is no proper planning on building maintenance. Furthermore, maintenance operation is executed in reactive basis, whereby the maintenance task is performed after the system defect is determined [18].

Currently, the facilities management and maintenance management practices for most of the buildings rely heavily on corrective maintenance, where the item is repaired or replaced as it has damaged or broken [19]. In Malaysia, many buildings are even having lack of adequate maintenance [7]. Corrective maintenance is often carried out instead of other proper maintenance strategies. The statement is proven by Nik-Mat, Kamaruzzaman and Pitt [20], who mentioned that the conventional maintenance strategy is dominantly applied compared to integrated facilities management systems although the new approach has been proven to be advantageous in maintenance operations.

However, higher maintenance cost is required to restore a building to its original function and purpose [21]. Thus, to overcome the issue of high building maintenance cost, the criteria such as cost performance, safety, security and others should be taken into consideration in the review, evaluation and assessment of the maintenance policies and strategies [22]. For example, Malaysian Government has taken the initiative by instructing their agencies to carry out maintenance operations from the early stage to avoid risk of higher maintenance cost due to continuous deterioration through time [23].

Moghaddam and Usher [24] revealed that preventive maintenance involves maintenance tasks such as inspection, monitoring, cleaning, lubrication, adjustment, alignment, repair, replacement and maintenance of building's and systems' components before failures or system breakdowns occur. It is based on component reliability characteristics and aimed to reduce the probability of component failure, as well as to minimise the system downtime [25]. Thus, preventive maintenance is more effective than corrective maintenance in terms of cost and reliability [26].

Scheduled maintenance, as one of the preventive maintenance strategies, is performed at time interval basis to overcome the problem of wear and tear, as well as to minimise the probability of system failure [27, 28]. The maintenance personnel always plan the time interval of inspection or maintenance ahead to ensure the availability or normal operation of the building systems, such as lift, water pump and others. They usually follow the manufacturers' data or standard guides of the service life estimates to determine the maintenance interval and requirement [29].

Basically, scheduled maintenance requires an interruption of the system or temporary disabling the system for part replacement and system testing [30, 31]. It only back into operation when the maintenance task is completed. In some cases, often interruption of the components may affect the efficiency of the system. On the other hand, unavailable or delayed maintenance action at the right time may cause unwanted damages to the system [32].

Therefore, it is necessary to apply appropriate maintenance inspections or treatments at the right time to extend service life of the components [33]. In fact, implementation of scheduled maintenance with minimal maintenance cost might not guarantee the reliability and availability of the systems [34]. In order to enhance the effectiveness of the maintenance strategy, it is compulsory to determine the optimal time interval between the maintenance tasks.

Whereby, residents' satisfaction encompasses the services and facilities provided, as well as the management practices such as the maintenance and repair service [35]. The routine of inspection and maintenance is likely to affect the maintenance performance and also the residents' satisfaction. It ensures the building sustainability by maximising the availability of building services and facilities, extending the lifespan of a building, and reducing the cost of failure [36]. Next, the following section discusses the needs of maintenance in residential building, specifically the high-rise building that equips with complex and comprehensive facilities and services.

\subsection{Residential building maintenance}

According to Hui [37], residential buildings are subjected to heavy usage and stress under different circumstances, such as wear and tear, climate change and ageing process. As a result of high occupancy rate, proper operation and maintenance are compulsory to reduce the deteriorating rate or restore the buildings and systems to an acceptable operating condition. It helps to sustain the property value and maintain high return on investment [2]. Meanwhile, Yusof, Abdullah, Zubedy and Mohd Najib [3] demonstrated that to keep property habitable and building operable are the important reasons of performing maintenance works.

From demanding for living space, the public now is demanding more towards quality living. Instead of buying a house with complete amenities, the house buyers prefer to buy a home equipped with value added facilities like security, gymnasium, swimming pool, landscaping and others [2]. The available of building services include electricity supply, water supply, sewerage and drainage, telecommunication, lifts and fire 
services system, as well as the building facilities promotes the residential satisfaction [38]. Inevitably, all the facilities require maintenance to retain their conditions in satisfactory standard. The maintenance works on residential buildings create opportunities to gain economic and social benefits while reducing carbon footprints [39].

Furthermore, building maintenance and building safety are closely related to each other. Maintenance of safety systems like fire services system and security system ensures the safety of occupants. However, unsatisfactory fire safety management and lack of maintenance of fire services system is one of the issues accounted in residential buildings [40]. This would increase the risk of safety issue towards the buildings and occupants. Lai and Yik [1] claimed that the quality of maintenance management is critical to the operation of the building services and facilities. The performance of the services and facilities may affect the health, safety and enjoyment of the occupants. Yusof, Abdullah, Zubedy and Mohd Najib [3] confirmed that the maintenance works are vital to maintain the safety and health of residents.

Therefore, implementation of preventive maintenance is vital to retain the condition of buildings and systems, property values, as well as safety and health of the residents. In order to ensure the effectiveness of preventive maintenance strategy, the frequency of inspection and interval of maintenance must be reviewed. The next section explains the methods utilised for this research.

\section{Method}

Critical review was conducted to identify the problems in (discussed in Section 1) and needs of (discussed in Section 2) effective maintenance in high-rise residential building that guided to the formulation of research aim. In order to establish the relationship between frequency of routine maintenance and maintenance performance, an extensive search and analytical review of the literature related to the topics were performed. This method was adopted from the researches done by Simoes, Gomes and Yasin [41] and Roda, Macchi, Fumagalli and Viveros [42]. The literature search and review covered publications of journal articles, conference proceedings, and books.

The reviewed publications were published as 36 journal articles, 2 conference proceedings and 2 books from year 1987 to 2014. Table 1 lists the publication sources and number of publications taken into account from each of them. The publications covered either the scopes of building and construction or maintenance management, which were relevant to this research.

Table 1: List of sources for literature review and number of publications considered

\begin{tabular}{lr}
\hline Source Title & $\begin{array}{r}\text { No. of } \\
\text { Publications }\end{array}$ \\
\hline Applied Energy & 1 \\
Building and Environment & 1 \\
\hline
\end{tabular}

\begin{tabular}{lr}
\hline Building Engineer Journal & 1 \\
Building Research and Information & 1 \\
Construction and Building Materials & 1 \\
Engineering, Construction and Architectural & 1 \\
Management & \\
Facilities & 1 \\
Gradevinar & 1 \\
Habitat International & 2 \\
Housing Studies & 1 \\
International Journal of Production & 1 \\
Economics & 1 \\
International Journal of Production Research & 1 \\
International Journal of Strategic Property & \\
Management & 1 \\
Journal of Building Appraisal & 1 \\
Journal of Building Property Review & 1 \\
Journal of Cleaner Production & 2 \\
Journal of Facilities Management & 1 \\
Journal of Performance of Constructed & \\
Facilities & 5 \\
Journal of Quality in Maintenance & \\
Engineering & \\
Procedia - Social and Behavioral Sciences & \\
Procedia Engineering & 2 \\
Reliability Engineering and System Safety & 1 \\
Renewable Energy & 1 \\
Social Indicators Research & 1 \\
Structural Survey & 2 \\
Structure and Infrastructure Engineering & \\
Others (conference proceedings and books) & \\
Total & \\
\hline
\end{tabular}

Then, analysis of literature contents was conducted and it led to the development of theory of routine maintenance and performance. The analysis results are presented and discussed in next section.

\section{Result}

The researchers throughout the time discuss the building maintenance issues extensively. Based on systematic content analysis of the researches, three main maintenance issues are identified. Table 2 shows the maintenance issues that the researchers discuss and their number of citations. The citation frequency of different maintenance issues has been taken as an indicator of the concern given by the scientific literature to each issue.

Table 2: Citation of the maintenance issues in publications

\begin{tabular}{lccc}
\hline Citation & $\begin{array}{c}\text { Neglect } \\
\text { towards } \\
\text { importance } \\
\text { of } \\
\text { maintenance }\end{array}$ & $\begin{array}{c}\text { Lack of } \\
\text { preventive } \\
\text { maintenance } \\
\text { plan }\end{array}$ & $\begin{array}{c}\text { High } \\
\text { maintenance } \\
\text { cost }\end{array}$ \\
\hline $\begin{array}{l}\text { Tiun [2] } \\
\text { Yusof, }\end{array}$ & $\mathrm{X}$ & $\mathrm{X}$ & \\
$\begin{array}{l}\text { Abdullah, } \\
\text { Zubedy and }\end{array}$ & $\mathrm{X}$ & $\mathrm{X}$ & \\
$\begin{array}{l}\text { Mohd Najib [3] } \\
\text { Hsieh [4] }\end{array}$ & & & \\
Abdul Karim & & $\mathrm{X}$ & \\
[5] & & $\mathrm{X}$ & \\
El-Haram and & & & $\mathrm{X}$ \\
Horner [6] & & $\mathrm{X}$ & $\mathrm{X}$ \\
$\begin{array}{l}\text { Lateef [7] } \\
\text { Kamaruzzaman }\end{array}$ & $\mathrm{X}$ & $\mathrm{X}$ & \\
\hline
\end{tabular}




\begin{tabular}{|c|c|c|c|}
\hline \\
\hline \multicolumn{2}{|l|}{$\begin{array}{l}\text { and Zawawi [8] } \\
\text { Ruslan [9] }\end{array}$} & $\mathrm{X}$ & \\
\hline \multicolumn{4}{|l|}{ Olanrewaju, } \\
\hline Idrus and & & $\mathrm{X}$ & \\
\hline \multicolumn{4}{|l|}{ Khamidi [18] } \\
\hline Lavy [19] & & $\mathrm{X}$ & \\
\hline \multicolumn{4}{|l|}{ Nik-Mat, } \\
\hline \multicolumn{4}{|l|}{ and Pitt [20] } \\
\hline Seeley [21] & & & $\mathrm{X}$ \\
\hline $\begin{array}{l}\text { Mohd Nizar } \\
\text { [22] }\end{array}$ & $\mathrm{X}$ & & \\
\hline $\begin{array}{l}\text { Mohd-Noor, } \\
\text { Hamid, Abdul- } \\
\text { Ghani and } \\
\text { Haron [23] }\end{array}$ & $\mathrm{X}$ & $\mathrm{X}$ & \\
\hline $\begin{array}{l}\text { Moghaddam } \\
\text { and Usher [24] }\end{array}$ & & $\mathrm{X}$ & \\
\hline $\begin{array}{l}\text { Fouladgar, } \\
\text { Yazdani- }\end{array}$ & & & \\
\hline $\begin{array}{l}\text { Chamzini, } \\
\text { Lashgari, } \\
\text { Zavadskas and } \\
\text { Turskis [25] }\end{array}$ & & $\mathrm{X}$ & \\
\hline $\begin{array}{l}\text { Batun and } \\
\text { Azizoğlu [26] }\end{array}$ & & $\mathrm{X}$ & \\
\hline $\begin{array}{l}\text { Total number } \\
\text { of citation }\end{array}$ & 5 & 14 & 3 \\
\hline
\end{tabular}

The most common building maintenance issue, revealed in 14 publications, relates to the lack of preventive maintenance plan. For instance, Lateef [7] argued that there is a huge backlog of building maintenance in Malaysia due to the ignorance towards proactive and preventive maintenance. Other maintenance issues include neglect towards importance of maintenance and high maintenance cost, discussed in 5 and 3 publications respectively. Thus, the study focuses on the implementation of preventive maintenance strategy.

Based on detailed content analysis of the reviewed publications, the routine maintenance of facilities and building services is vital and it can be influential towards the maintenance performance. In other words, the interval between inspections or maintenance works may affect the maintenance performance significantly. Paulo, Branco and de Brito [17] inadequate interval between maintenance actions leads to the poor consequences like system defect. Table 3 lists the publications that have cited the importance of routine maintenance.

Table 3: Citation of the routine maintenance and its influence towards maintenance performance in publications

\begin{tabular}{ll}
\hline Citation & \\
\hline Importance of routine & Au-Yong, Ali and Ahmad [10]; \\
maintenance & Flores-Colen and De Brito [11]; \\
& Forster and Kayan [12]; Edward, Holt \\
& and Harris [13]; Eti, Ogaji and Probert \\
& [14]; Irigaray and Gilabert [15]; Wu, \\
& Clements-Croome, Fairey, Albany, \\
& Sidhu, Desmond and Neale [16]; \\
& Grant and Ries [29]; Paulo, Branco \\
& and de Brito [17]; Bevilacqua and \\
& Braglia [27]; Hameed, Ahn and Cho \\
& [28]; Swanson [30]; Tsang [31]; \\
& Narayan [32]; Chen, Lin and Luo \\
\hline
\end{tabular}

[33]; Ahn and Kim [34]; Varady and Carrozza [35]; Ahmad, Nur Azfahani and Nor Haniza [36]

Its influence towards Edward, Holt and Harris [13]; Eti, maintenance Ogaji and Probert [14]; Irigaray and performance Gilabert [15]; Wu, Clements-Croome, Fairey, Albany, Sidhu, Desmond and Neale [16]; Paulo, Branco and de Brito [17]; Bevilacqua and Braglia [27]; Hameed, Ahn and Cho [28]; Swanson [30]; Tsang [31]; Narayan [32]; Chen, Lin and Luo [33]; Ahn and Kim [34]; Varady and Carrozza [35]; Ahmad, Nur Azfahani and Nor Haniza [36]

Whereby unavailable or delay to carry out maintenance action at the right time may cause damages to the building elements or system components [32]; while tight routine maintenance may require frequent intrusion of the system that causes maintenance downtime that affect the residents' activities [30]. The relationship of the routine maintenance and maintenance performance remains uncertain. Therefore, there is a need to study on the relationship between routine maintenance of facilities and services and maintenance performance. In this context, the following research questions are relevant:

i) What are the building facilities \& services that require routine maintenance?

ii) How does the routine maintenance influence the maintenance performance?

iii) What is the appropriate routine of maintenance in order to optimise the maintenance performance?

Based on the research questions, a theoretical framework as shown in Figure 1 is developed for future research. The research aims to identify the appropriate routine of maintenance for the facilities and services in high-rise residential buildings to improve the maintenance performance.

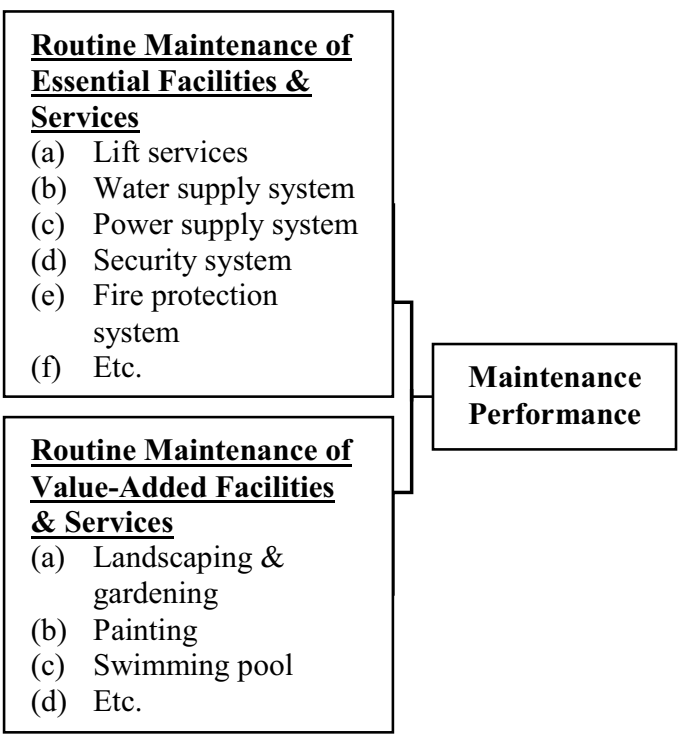

Figure 1: Theoretical framework for future research 


\section{Conclusion}

This research examines the maintenance issues in construction industry, specifically the residential buildings. Literature demonstrates that lack of preventive maintenance plan is the main issue in building maintenance sector. Introduction and implementation of preventive maintenance is necessary to enhance maintenance performance. Scheduled maintenance as one of the preventive maintenance strategies requires routine inspection and maintenance at specific interval. Many researchers argue that the interval of inspection and maintenance brings impact to the maintenance performance. Therefore, there is a need to study on the relationship between routine maintenance of facilities and services and maintenance performance. The study will focus on two aspects, which are routine maintenance of essential facilities \& services and value-added facilities \& services.

\section{Acknowledgement}

The authors gratefully acknowledge the financial support of the University Malaya Research Fund Assistance (BKP), grant no. BK021-2015 established at the Institute of Research Management \& Monitoring (IPPP), University of Malaya.

\section{References}

1. J. H. K. Lai and F. W. H. Yik, Building and Environment 46 (1), 165-175 (2011).

2. L. T. Tiun, presented at the 2nd NAPREC Conference, Bangi, Selangor, 2009 (unpublished).

3. N. A. Yusof, S. Abdullah, S. Zubedy and N. U. Mohd Najib, Procedia - Social and Behavioral Sciences 62, 508-513 (2012).

4. H. R. Hsieh, Habitat International 33 (1), 73-80 (2009).

5. H. Abdul Karim, Procedia - Social and Behavioral Sciences 35, 44-53 (2012).

6. M. A. El-Haram and M. W. Horner, Journal of Quality in Maintenance Engineering 8 (2), 115-123 (2002).

7. O. A. Lateef, Journal of Building Appraisal 4 (3), 207-214 (2008).

8. S. N. Kamaruzzaman and E. M. A. Zawawi, Journal of Facilities Management 8 (1), 75-81 (2010).

9. N. Ruslan, in National Asset and Facilities Management (NAFAM) Convention, National Asset and Facility Management Development, 13 August (Kuala Lumpur, Malaysia, 2007).

10. C. P. Au-Yong, A. S. Ali and F. Ahmad, Gradevinar 65 (9), 803-809 (2013).

11. I. Flores-Colen and J. De Brito, Construction and Building Materials 24 (9), 1718-1729 (2010).

12. A. M. Forster and B. Kayan, Structural Survey 27 (3), 210-229 (2009).

13. D. J. Edward, G. D. Holt and F. C. Harris, Journal of Quality in Maintenance Engineering 4 (1), 25-37 (1998).
14. M. C. Eti, S. O. T. Ogaji and S. D. Probert, Applied Energy 83 (10), 1163-1179 (2006).

15. A. A. Irigaray and E. Gilabert, Journal of Quality in Maintenance Engineering 15 (2), 151-166 (2009).

16. S. Wu, D. Clements-Croome, V. Fairey, B. Albany, J. Sidhu, D. Desmond and K. Neale, Engineering, Construction and Architectural Management 13 (2), 136-153 (2006).

17. P. V. Paulo, F. Branco and J. de Brito, Struct. Infrastruct. Eng. 10 (3), 388-397 (2014).

18. A. L. Olanrewaju, A. Idrus and M. F. Khamidi, Structural Survey 29 (5), 397-410 (2011).

19. S. Lavy, Journal of Facilities Management 6 (4), 303 315 (2008).

20. N. E. M. Nik-Mat, S. N. Kamaruzzaman and M. Pitt, Procedia Engineering 20, 329-338 (2011).

21. I. H. Seeley, Building Maintenance, 2nd ed. (Palgrave, New York, 1987).

22. B. J. Mohd Nizar, Journal of Building Property Review 14 (7), 8-9 (1998).

23. N. Mohd-Noor, M. Y. Hamid, A. A. Abdul-Ghani and S. N. Haron, Procedia Engineering 20, 435-444 (2011).

24. K. S. Moghaddam and J. S. Usher, Journal of Quality in Maintenance Engineering 16 (3), 271-287 (2010).

25. M. M. Fouladgar, A. Yazdani-Chamzini, A. Lashgari, E. K. Zavadskas and Z. Turskis, International Journal of Strategic Property Management 16 (1), 85-104 (2012).

26. S. Batun and M. Azizoğlu, International Journal of Production Research 47 (7), 1753-1771 (2009).

27. M. Bevilacqua and M. Braglia, Reliability Engineering and System Safety 70 (1), 71-83 (2000).

28. Z. Hameed, S. H. Ahn and Y. M. Cho, Renewable Energy 35 (5), 879-894 (2010).

29. A. Grant and R. Ries, Building Research and Information 41 (2), 168-186 (2013).

30. L. Swanson, International Journal of Production Economics 70, 237-244 (2001).

31. A. H. C. Tsang, Journal of Quality in Maintenance Engineering 1 (3), 3-17 (1995).

32. V. Narayan, Effective Maintenance Management: Risk and Reliability Strategies for Optimizing Performance. (Industrial Press Inc, New York, 2003).

33. D.-H. Chen, D.-F. Lin and H.-L. Luo, Journal of Performance of Constructed Facilities 17 (3), 136-143 (2003).

34. S. Ahn and W. Kim, Struct. Infrastruct. Eng. 7 (4), 307-314 (2011).

35. D. P. Varady and M. A. Carrozza, Housing Studies 15 (6), 797-825 (2000).

36. R. Ahmad, A. Nur Azfahani and I. Nor Haniza, Building Engineer Journal 81 (4), 30-33 (2006).

37. E. Y. Y. Hui, Facilities 23 (1/2), 47-62 (2005).

38. M. A. Mohit, M. Ibrahim and Y. R. Rashid, Habitat International 34, 18-27 (2010).

39. Y. H. Chiang, J. Li, L. Zhou, F. K. W. Wong and P. T. I. Lam, Journal of Cleaner Production, doi: 10.1016/j.jclepro.2014.1007.1069 (2014).

40. Y. Yau, C. D. W. Ho and K. W. Chau, Social Indicators Research 89, 501-521 (2008). 
41. J. M. Simoes, C. F. Gomes and M. M. Yasin, Journal of Quality in Maintenance Engineering 17 (2), 116137 (2011).

42. I. Roda, M. Macchi, L. Fumagalli and P. Viveros, Journal of Manufacturing Technology Management 25 (4), 528-549 (2014). 